\title{
Acclimation of photosynthetic temperature optima of temperate and boreal tree species in response to experimental forest warming
}

\author{
KERRIE M. SENDALL ${ }^{1}$, PETER B. REICH ${ }^{1,2}, \mathrm{CHANGMING} \mathrm{ZHAO}^{3}, \mathrm{HOU}_{\mathrm{JIHUA}}{ }^{4}$, \\ XIAORONG WEI ${ }^{5}$, ARTUR STEFANSKI ${ }^{1}$, KAREN RICE ${ }^{1}$, ROY L. RICH ${ }^{1}$ and \\ REBECCA A. MONTGOMERY ${ }^{1}$ \\ ${ }^{1}$ Department of Forest Resources, University of Minnesota, 1530 Cleveland Avenue N, St. Paul, MN 55108, USA, ${ }^{2}$ Hawkesbury \\ Institute for the Environment, University of Western Sydney, Penrith, NSW 2753, Australia, ${ }^{3}$ State Key Laboratory of Grassland \\ Agro-Ecosystems, School of Life Sciences, Lanzhou University, Lanzhou 730000, China, ${ }^{4}$ Key Laboratory for Forest Resources $\mathcal{E}$ \\ Ecosystem Processes of Beijing, Beijing Forestry University, Beijing 100083, China, ${ }^{5}$ Institute of Soil and Water Conservation, \\ Northwest AEF University, Yangling 712100, China
}

\begin{abstract}
Rising temperatures caused by climate change could negatively alter plant ecosystems if temperatures exceed optimal temperatures for carbon gain. Such changes may threaten temperature-sensitive species, causing local extinctions and range migrations. This study examined the optimal temperature of net photosynthesis $\left(T_{\text {opt }}\right)$ of two boreal and four temperate deciduous tree species grown in the field in northern Minnesota, United States under two contrasting temperature regimes. We hypothesized that $T_{\text {opt }}$ would be higher in temperate than co-occurring boreal species, with temperate species exhibiting greater plasticity in $T_{\text {opt }}$, resulting in better acclimation to elevated temperatures. The chamberless experiment, located at two sites in both open and understory conditions, continuously warmed plants and soils during three growing seasons. Results show a modest, but significant shift in $T_{\text {opt }}$ of $1.1 \pm 0.21{ }^{\circ} \mathrm{C}$ on average for plants subjected to a mean $2.9 \pm 0.01{ }^{\circ} \mathrm{C}$ warming during midday hours in summer, and shifts with warming were unrelated to species native ranges. The $1.1{ }^{\circ} \mathrm{C}$ shift in $T_{\text {opt }}$ with $2.9{ }^{\circ} \mathrm{C}$ warming might be interpreted as suggesting limited capacity to shift temperature response functions to better match changes in temperature. However, $T_{\text {opt }}$ of warmed plants was as well-matched with prior midday temperatures as $T_{\text {opt }}$ of plants in the ambient treatment, and $T_{\text {opt }}$ in both treatments was at a level where realized photosynthesis was within 90-95\% of maximum. These results suggest that seedlings of all species were close to optimizing photosynthetic temperature responses, and equally so in both temperature treatments. Our study suggests that temperate and boreal species have considerable capacity to match their photosynthetic temperature response functions to prevailing growing season temperatures that occur today and to those that will likely occur in the coming decades under climate change.
\end{abstract}

Keywords: climate change, ecotone, maximum photosynthetic rate, range shifts, thermal plasticity

Received 1 May 2014 and accepted 15 September 2014

\section{Introduction}

Continued warming of global land surface temperatures by $1.1-6.4{ }^{\circ} \mathrm{C}$ is likely over the next century, with variation at diurnal, regional, and seasonal scales (IPCC, 2013). Range shifts and local extinctions are expected in response to warming, given that range boundaries tend to follow temperature isolines and species may differ in their sensitivity to changing temperature (Sykes \& Prentice, 1996; Thomas et al., 2004; Jump et al., 2006; Gunderson et al., 2010). Extreme climate events (i.e., heat waves, severe drought), particularly at warm, lower latitude range limits, may lead to

Correspondence: K. M. Sendall, tel. +612940 0133, fax +612 625 5212, e-mail: senda002@umn.edu dieback at the trailing end of a species distribution (Bigler et al., 2006; Zimmermann et al., 2009), while factors such as increased levels of competition at the warmer end of species distributions may also partially determine range limits (Woodward, 1987). The physiological mechanisms that govern geographic range limits are not well understood, which prevents models from accurately characterizing the response of forest systems to a changing climate (Hijmans \& Graham, 2006).

There are conflicting results as to whether species' temperature optima vary among species in parallel with differences in their current overall geographic (climate) distribution. A few studies have shown that taxa with lower latitude distributions have higher temperature optima compared to those from cooler, higher latitude locations (Hill et al., 1988; Cunningham \& Read, 
2002; Robakowski et al., 2012), but others have found no evidence for temperature optima to be related to climatic distribution (Battaglia et al., 1996; Teskey \& Will, 1999; Gunderson et al., 2000, 2010). Future climate warming throughout species' ranges may lead to air and leaf temperatures that exceed current photosynthetic temperature optima, which could lead to reduced photosynthetic capacity and carbon gain, and thus negatively affect not only carbon gain but also potentially rates of growth and survival (Sage et al., 2008).

The ability of species to adjust their photosynthetic temperature optima to changes in temperature (acclimation) could act to limit reductions in gas-exchange rates (Berry \& Bjorkman, 1980; Kattge \& Knorr, 2007; Gunderson et al., 2010; Ghannoum \& Way, 2011). Species growing near their colder, higher latitude range limits may respond positively to warming and such responses may be enhanced by gene transfer (mostly from pollen) from the warmer center of the range (Davis \& Shaw, 2001). Conversely, species growing near their lower latitude, warm range limits may have limited potential to respond to warming (Berry \& Bjorkman, 1980; Tjoelker et al., 1998; Gunderson et al., 2010; Ghannoum \& Way, 2011) and such responses may be retarded by lack of gene flow from populations adapted to warmer temperatures because beyond the range edge individuals do not survive or are out-competed in the unfavorable conditions (Davis \& Shaw, 2001). Dillaway \& Kruger (2010) compared acclimation of two boreal and two temperate species across a climatic gradient, and found little evidence for temperature acclimation in general, or for differences in acclimation capacities among temperate and boreal species. In contrast, Cunningham \& Read (2002) compared acclimation of four temperate and four tropical rainforest species, and observed higher temperature optima and greater acclimation capacities for tropical compared to temperate species. While six of the eight species measured in their study were collected as seedlings from natural populations (the remaining two were grown from seed), the seedlings were grown in a greenhouse for 1 year prior to the experiment, so it is not clear whether these results translate to field conditions.

Acclimation potential (of photosynthesis) has rarely been incorporated into physiological and ecosystem models (Medlyn et al., 2002a,b; Kattge \& Knorr, 2007), suggesting that models may over- or underestimate how species respond to temperature change and how ecosystem productivity is affected by climate change (Hanson et al., 2005). It is important to determine the degree of acclimation possible for a wide variety of species, given that the impact of warming may be reduced if species are able to undergo significant shifts in temperature optima that keep their physiology more clo- sely matched to prevailing conditions. Researchers who have investigated temperature acclimation have often studied seedlings in growth chambers kept at uniform day/night temperatures (e.g., Tjoelker et al., 1998; Teskey \& Will, 1999) and rarely measured complete temperature response curves (but see Cunningham \& Read, 2002). Thus, less is known about the degree and timing of acclimation in natural settings with thermal variability (e.g., Dougherty et al., 1979). To measure species across a wide range of temperatures in natural systems, field studies have made use of latitudinal and altitudinal gradients, as well as seasonal changes in temperature (Slatyer \& Ferrar, 1977; Dougherty et al., 1979; Han et al., 2004; Dillaway \& Kruger, 2010). While these types of studies often show variation in temperature responses of photosynthesis, there are many other biotic and abiotic factors such as soil moisture, soil nutrient availability, leaf age and ontogeny, and leaf traits like leaf mass per area, that are known to vary seasonally or along latitudinal and altitudinal gradients that may affect the magnitude of acclimation responses (Harris et al., 2006; Homann et al., 2007). While past research using growth chambers and temperature gradients has detected acclimation across wide temperature ranges (i.e., comparisons of plants in growth chambers set $10^{\circ}$ apart), it is uncertain whether acclimation will also occur in response to smaller temperature increases $\left(2-5{ }^{\circ} \mathrm{C}\right)$ when plants are subjected to otherwise comparable field conditions (e.g., soils, precipitation, fluctuating baseline temperatures) (but see Gunderson et al., 2010).

The goal of this study was to measure the plasticity of temperature optima, and photosynthetic rates at the optima, to conditions similar to regional predictions of climate change. Mean summer temperatures in central North America are predicted to increase by $3.1-5.1{ }^{\circ} \mathrm{C}$ over the next century, with increased frequency and duration of drought conditions (Christensen et al., 2007). We selected tree species that co-occur within the ecotone but have different overall distributions (i.e., boreal vs. temperate) to compare acclimation capacities, given that direct comparisons of species originating from different biomes are rare, particularly comparisons in natural settings with thermal variability.

We measured photosynthetic temperature response curves of two boreal and four temperate broad-leaved tree species that co-occur in North America (Table 1). Thus, we were able to compare acclimation potentials for species from a broad distribution of range limits and habitats. Local ecotypes of each species were exposed to either ambient air temperatures or average midday warming of $+2.9 \pm 0.01{ }^{\circ} \mathrm{C}$ above ambient. Measurements were made at the two sites of a chamberless field warming experiment known as Boreal 
Table 1 Study species with southern (lower latitude) range limits and shade tolerance rankings. Shade tolerance rankings were obtained from Niinemets \& Valladares (2006)

\begin{tabular}{|c|c|c|c|}
\hline Species & & $\begin{array}{l}\text { Southern } \\
\text { range limit }\end{array}$ & $\begin{array}{l}\text { Shade tolerance } \\
\text { ranking }\end{array}$ \\
\hline Acer rubrum L. & \multirow[t]{4}{*}{ Temperate } & $31.2^{\circ} \mathrm{N}$ & $3.44 \pm 0.23$ \\
\hline Quercus rubra L. & & $34.8^{\circ} \mathrm{N}$ & $2.75 \pm 0.18$ \\
\hline $\begin{array}{l}\text { Acer saccharum } \\
\text { Marsh. }\end{array}$ & & $36.5^{\circ} \mathrm{N}$ & $4.76 \pm 0.11$ \\
\hline $\begin{array}{l}\text { Quercus } \\
\text { macrocarpa } \\
\text { Michx. }\end{array}$ & & $40.7^{\circ} \mathrm{N}$ & $2.71 \pm 0.27$ \\
\hline $\begin{array}{l}\text { Betula } \\
\text { papyrifera } \\
\text { Marsh. }\end{array}$ & \multirow[t]{2}{*}{ Boreal } & $44.2^{\circ} \mathrm{N}$ & $1.54 \pm 0.16$ \\
\hline $\begin{array}{l}\text { Populus } \\
\text { tremuloides } \\
\text { Michx. }\end{array}$ & & $44.3^{\circ} \mathrm{N}$ & $1.21 \pm 0.18$ \\
\hline
\end{tabular}

Forest Warming at an Ecotone in Danger (B4WarmED), in northern Minnesota, USA within the boreal foresttemperate forest ecotone (Table 2). We tested the following hypotheses: (H1) photosynthetic temperature optima will correlate with species' climate distributions, with temperate species exhibiting higher temperature optima relative to boreal species, $(\mathrm{H} 2 \mathrm{a})$ all species will experience some degree of acclimation in temperature optima and maximum photosynthetic rates in response to $2.9 \pm 0.01{ }^{\circ} \mathrm{C}$ average warming, but (H2b) boreal species growing near their warmer, lower latitude range limits will have limited acclimation capacities relative to temperate species near their cooler, higher latitude range limits and thus, (H3) the negative impact of warming on photosynthetic rates will be ameliorated less so in boreal species as compared to temperate species.

\section{Materials and methods}

\section{Site and species descriptions}

The experiment was located at two sites; the Cloquet Forestry Center, Cloquet MN and at a colder, higher latitude site near Ely, MN, the Hubachek Wilderness Research Center (Table 2).
Both are University of Minnesota field stations and were chosen because of their location within the boreal forest-temperate forest ecotone. At both sites, our warming experiments were located on coarse-textured upland soils in 40-60 year old mixed aspen-birch-fir stands scattered with pine, spruce, and other species.

Treatments were positioned in both closed $(\approx 5-10 \%$ of full sunlight) and relatively open $(\approx 40-60 \%$ of full sunlight) overstory conditions. Both closed and open plots were exposed to experimental treatments because regeneration in both habitat types is important in determining boreal forest canopy composition, given the spatial and temporal patterns of natural and anthropogenic disturbances (Heinselman, 1973; Grigal \& Ohmann, 1975; Frelich \& Reich, 1995). In addition, our species vary in light requirements for regeneration so both habitat types were required for a broad test of warming effects on regeneration in southern boreal forests (Table 1).

Our six native deciduous hardwood species included four temperate and two boreal species (Table 1), all of which are present in the ecotonal region. Local ecotypes of all seedlings planted were obtained from the Minnesota Department of Natural Resources; both sites are in the same DNR seed zone. All seeds came from Minnesota sources $\leq 80 \mathrm{~km}$ north or south of the latitude of the Cloquet site. Southern (lower latitude) range limit of each species was defined as the latitude in central North America (west of 86 degrees longitude and east of 100 degrees longitude) above which $95 \%$ of individuals are found; these values were calculated using US Forest Service FIA data.

\section{Experimental design}

For a detailed explanation of the experimental design, see Rich et al. (in review). The overall experimental design was a 2 site $\times 2$ habitat $\times 2$ treatment factorial, with six replicates of each for a total of 48 circular $3 \mathrm{~m}$ diameter plots. Treatments included two levels of simultaneous plant and soil warming (ambient and a mean elevation of $+3.4 \pm 0.01{ }^{\circ} \mathrm{C}$ over day and night and the entire growing season) achieved through use of infrared heat lamps and buried soil heating cables (dummy lamps and soil cables in the ambient plot). Although warming in winter can have important impacts on ecosystem processes, the low levels of biological activity at $<0{ }^{\circ} \mathrm{C}$, the potential artefactual effects of our warming treatments on snow melt and freeze/thaw cycles, and the high expense of warming yearround in aggregate led us to decide not to warm in winter. Moreover, ambient plot soil data show that soil temperature disassociates with air temperature during winter months, probably due to the insulative snow cover.

Table 2 Site descriptions. Mean minimum and maximum temperatures were measured on site. Reported temperature measurements are the daily minimum of the coldest month and the daily maximum of the warmest month averaged for 2009-2011

\begin{tabular}{llllll}
\hline Site & Lat/Long & $\begin{array}{l}\text { Altitude } \\
\text { a.s.l. }(\mathrm{m})\end{array}$ & $\begin{array}{l}\text { Mean annual } \\
\text { precipitation }(\mathrm{mm})\end{array}$ & $\begin{array}{l}\text { Mean minimum } \\
\text { temperature }{ }^{\circ} \mathrm{C}\end{array}$ & $\begin{array}{l}\text { Mean maximum } \\
\text { temperature }\end{array}$ \\
\hline Cloquet, $\mathrm{CN}$ & $46^{\circ} 40^{\prime} \mathrm{N}, 92^{\circ} 31 \mathrm{~W}$ & 382 & 807 & $-30.6{ }^{\circ} \mathrm{C}$ & $34.4^{\circ} \mathrm{C}$ \\
Ely, $\mathrm{MN}$ & $47^{\circ} 56^{\prime} \mathrm{N}, 91^{\circ} 45 \mathrm{~W}$ & 415 & 722 & $-34.8^{\circ} \mathrm{C}$ & $36.5^{\circ} \mathrm{C}$ \\
\hline
\end{tabular}


Chamberless warming was achieved via a feedback control that acted concurrently and independently at the plot scale to maintain a fixed temperature differential from ambient conditions. The rationale for this design was that simultaneous warming above- and belowground provides a more realistic treatment than does either in isolation (as decadal-scale changes in mean growing season soil temperatures are likely to mirror long-term changes in mean air temperatures). Moreover, above- and belowground measurement data show the established warming treatments emulated observed diurnal, seasonal, and annual patterns in temperature and generally matched historical warming during the past half century (in terms of differences among times of day or seasons) (Rich et al. in review). The degree of warming diminished slightly as the experiment progressed and increasing amounts of plant biomass transpired greater amounts of water, limiting warming per unit radiation added. Although the amount of energy put toward warming each $+3.4{ }^{\circ} \mathrm{C}$ plot was similar over the course of each day, we found that the degree of warming was lower during midday hours (09:00-15:00 hours) when ambient air temperatures were warmest (and when the greatest amount of photosynthesis occurs). On average, we achieved warming during midday hours of $+2.9 \pm 0.01{ }^{\circ} \mathrm{C}$ (Table 3) (Rich et al. in review). From this point forward, we refer the $+2.9{ }^{\circ} \mathrm{C}$ warming (rather than the $+3.4{ }^{\circ} \mathrm{C}$ warming) as it was the mean level of warming achieved during times of day when leaves are most photosynthetically active and thus represents thermal conditions to which temperature optima are likely to be best matched.

\section{Gas-exchange measurements}

Thermal responses of photosynthesis were measured using six Li-Cor 6400 portable photosynthesis systems (Li-Cor, Lincoln, NE, USA). A total of 1418 temperature response curves were measured throughout the growing seasons (June to September) of 2009 through 2011. Not all species were measured each year due to the time-consuming nature of the measurements. Temperature response curves were measured on detached foliage from a subsample of $\approx 5800$ seedlings planted in 2008 at both sites in these two warming treatment levels. Fully expanded, healthy leaves were chosen from individuals planted in open/ambient temperature, open/warmed $2.9^{\circ} \mathrm{C}$, closed/ambient temperature, and closed/warmed $2.9^{\circ} \mathrm{C}$ plots. Between 10 and 18 leaf samples were cut each morning and kept hydrated throughout the day using floral water pik tubes in a growth chamber that was used to efficiently achieve a broad range of measurement temperatures $(12,17,22,27,32$, and $37^{\circ} \mathrm{C}$ ) for multiple leaves simultaneously. We chose to measure detached foliage for two reasons: (i) to increase the number of leaves sampled due to rapid heating and cooling of leaf temperatures within the chamber, and (ii) to increase the range of measurement temperatures in each response curve. In a prior study that measured temperature response curves in situ using the thermoelectric block and Li-Cor 6400-88 Expanded Temperature Control Kit, leaf temperatures could only be decreased to $\approx 3-7{ }^{\circ} \mathrm{C}$ below the ambient temperature, and substantial amounts of time were spent waiting for target temperatures to be reached (Robakowski et al., 2012). Since summer daytime temperatures generally exceed $23{ }^{\circ} \mathrm{C}$ in both Ely and Cloquet, the lower end of each of our response curves would have been impossible to measure. Use of hydrated detached foliage entails several compromises. For example, leaves may have poorer water status than in the field if petioles suffer embolism, or be better hydrated if field plants are in dry soils. Stomatal function will also obviously be decoupled from stems and root signals. Although we thus caution against interpreting the absolute values of net photosynthesis as representative of plants in the field, there is no obvious reason that detachment should change the thermal response, and

Table 3 Ambient air temperatures $\left( \pm\right.$ SE) and the degrees above ambient achieved by the $2.9 \pm 0.01{ }^{\circ} \mathrm{C}$ target warming treatment averaged over each photosynthetic growing season (June 10 through September 27) at both sites and under both canopy conditions. Also shown are air temperatures averaged over the time of day, when plants are most photosynthetically active (09:00-15:00 hours) at the study sites

\begin{tabular}{|c|c|c|c|c|c|c|}
\hline Year & Site & $\begin{array}{l}\text { Overstory } \\
\text { condition }\end{array}$ & $\begin{array}{l}\text { Mean ambient } 24 \mathrm{~h} \\
\text { air temperatures }\left({ }^{\circ} \mathrm{C}\right)\end{array}$ & $\begin{array}{l}\text { Mean } 24 \mathrm{~h} \\
\text { warming } \\
\text { achieved }\left({ }^{\circ} \mathrm{C}\right)\end{array}$ & $\begin{array}{l}\text { Mean ambient } \\
\text { 09:00-15:00 } \\
\text { hours } \\
\text { temperatures }\left({ }^{\circ} \mathrm{C}\right)\end{array}$ & $\begin{array}{l}\text { Mean 09:00-15:00 } \\
\text { hours warming } \\
\text { achieved }\left({ }^{\circ} \mathrm{C}\right)\end{array}$ \\
\hline \multirow[t]{4}{*}{2009} & \multirow[t]{2}{*}{ Cloquet } & Closed & $15.6 \pm 0.04$ & $4.1 \pm 0.01$ & $19.4 \pm 0.06$ & $3.8 \pm 0.01$ \\
\hline & & Open & $15.7 \pm 0.05$ & $3.3 \pm 0.01$ & $22.3 \pm 0.07$ & $2.6 \pm 0.02$ \\
\hline & \multirow[t]{2}{*}{ Ely } & Closed & $15.9 \pm 0.04$ & $4.1 \pm 0.00$ & $19.0 \pm 0.06$ & $3.9 \pm 0.01$ \\
\hline & & Open & $16.1 \pm 0.05$ & $3.8 \pm 0.01$ & $21.7 \pm 0.08$ & $3.4 \pm 0.02$ \\
\hline \multirow[t]{4}{*}{2010} & \multirow[t]{2}{*}{ Cloquet } & Closed & $16.3 \pm 0.04$ & $3.6 \pm 0.01$ & $19.2 \pm 0.07$ & $3.2 \pm 0.01$ \\
\hline & & Open & $16.1 \pm 0.05$ & $3.1 \pm 0.01$ & $21.6 \pm 0.08$ & $2.0 \pm 0.02$ \\
\hline & \multirow[t]{2}{*}{ Ely } & Closed & $16.1 \pm 0.04$ & $4.0 \pm 0.01$ & $18.5 \pm 0.08$ & $3.8 \pm 0.01$ \\
\hline & & Open & $16.5 \pm 0.05$ & $3.3 \pm 0.01$ & $21.2 \pm 0.09$ & $2.6 \pm 0.02$ \\
\hline \multirow[t]{4}{*}{2011} & \multirow[t]{2}{*}{ Cloquet } & Closed & $15.7 \pm 0.04$ & $3.0 \pm 0.01$ & $18.8 \pm 0.07$ & $2.7 \pm 0.02$ \\
\hline & & Open & $15.5 \pm 0.05$ & $2.6 \pm 0.02$ & $20.8 \pm 0.08$ & $2.0 \pm 0.03$ \\
\hline & \multirow[t]{2}{*}{ Ely } & Closed & $17.0 \pm 0.04$ & $3.2 \pm 0.01$ & $19.9 \pm 0.08$ & $3.0 \pm 0.01$ \\
\hline & & Open & $17.1 \pm 0.06$ & $2.9 \pm 0.01$ & $22.5 \pm 0.10$ & $2.5 \pm 0.02$ \\
\hline
\end{tabular}


more importantly even if the thermal responses were influenced by detachment, it should influence leaves from ambient and warmed treatments similarly.

Each morning, collected leaves were placed in the growth chamber, which was set to $12{ }^{\circ} \mathrm{C}$. The leaf chamber of each Li-Cor was also placed inside the growth chamber and leaf temperature in the cuvette was set to correspond with the growth chamber temperature. Once both chambers reached the target temperature, leaves were clamped in the leaf chambers for a minimum of $10 \mathrm{~min}$ and three measurements were logged at 10 second intervals after readings had stabilized. Light was maintained in the leaf chamber at $1200 \mu \mathrm{mol} \mathrm{m} \mathrm{m}^{-2} \mathrm{~s}^{-1}$ using the LED light source for leaves collected from open plots, and $800 \mu \mathrm{mol} \mathrm{m} \mathrm{m}^{-2} \mathrm{~s}^{-1}$ for leaves from closed plots. Tests were made to ensure these levels were above those needed for light saturation. Air flow was set at 300-500 $\mu \mathrm{mol} \mathrm{s}^{-1}$ and reference $\mathrm{CO}_{2}$ concentrations were set at $400 \mu \mathrm{mol} \mathrm{mol}^{-1}$. Photosynthetic rates were measured for each leaf at $12{ }^{\circ} \mathrm{C}$, after which both the growth chamber and leaf temperature were set to $17^{\circ} \mathrm{C}$ and the process was repeated for all measurement temperatures in increasing order. Humidity within the leaf chamber was controlled to the best of our ability; we routed incoming air through desiccant at low temperatures to keep relative humidity below $70 \%$ and to avoid condensation, and allowed incoming air into the chamber at higher temperatures when humidity levels were lower. However, at $37^{\circ}$, vapor pressure deficit ranged from $\sim 1.5-4.5 \mathrm{kPa}$ and relative humidity often dropped to below $35 \%$, even when attempts were made to increase it. These attempts included adding water to the $\mathrm{CO}_{2}$ scrub column, lowering the flow rate within the leaf chamber, humidifying the air in the lab, and enclosing a hose attached to the intake valve with damp gauze.

\section{Fitting photosynthetic temperature response curves}

The photosynthetic temperature optimum for each measured leaf was estimated using nonlinear regression of the photosynthetic temperature response data:

$$
A_{(T)}=A_{\text {opt }}-b\left(T-T_{\text {opt }}\right)^{2},
$$

where $A_{(T)}$ is the measured net $\mathrm{CO}_{2}$ assimilation rate ( $\mu \mathrm{mol}$ $\mathrm{m}^{-2} \mathrm{~s}^{-1}$ ) at a leaf temperature $T$ and $b$ is a parameter describing the spread of the parabola (Battaglia et al., 1996). The vertex of each fit is considered the temperature optima of photosynthesis $\left(T_{\mathrm{opt}}\right)$, and $A_{\mathrm{opt}}$ is the rate of photosynthesis at $T_{\text {opt }}$. For a given $A_{\text {opt }}$ and $T_{\text {opt }}$, a smaller $b$ describes a relatively broader curve, while a larger $b$ describes a narrower curve. Curves were considered for analysis only when the fits of both the overall curve and the second-order polynomial were at least marginally significant $(P<0.20$ and $P<0.15$, respectively) and the $R^{2}$-value exceeded 0.75 . Thus, of the 1418 curves measured, only 880 curves that met our statistical criteria were used for analyses. We used these relatively nonconservative $P$-values given that our curves were made up of only six points, but ninety percent of our overall curve fits and $96 \%$ of second-order polynomial terms had $P$-values of $<0.10$. Curves were then screened to confirm that all points fit within
95\% confidence intervals and to ensure that $T_{\text {opt }}$ did not occur in the outer $3 \%$ of the distribution $\left(15.6{ }^{\circ} \mathrm{C}<T_{\text {opt }}<33.4{ }^{\circ} \mathrm{C}\right)$. In instances where one measurement point between 17 and $32{ }^{\circ} \mathrm{C}$ was negatively affecting the fit of the curve, it was removed and the curve was fit again using five points rather than six. For example, if a leaf had uncharacteristically low conductance and photosynthesis values at $17{ }^{\circ} \mathrm{C}$, its petiole was recut under water and measured again at $22{ }^{\circ} \mathrm{C}$, often recovering to more typical values. Using only curves that met stricter statistical standards did not materially influence the results.

Photosynthetic temperature optima were compared to 1, 3, 5, and 10 days prior temperature histories in ambient and warmed environments to examine how closely $T_{\text {opt }}$ matches prevailing temperature conditions. As it is unknown whether acclimation mostly closely matches temperatures experienced on very recent (days) or longer (weeks) time scales, we examined responses across a range of time windows. Results were similar for all, and we use the 5 days prior temperatures both because they had the strongest association with $T_{\text {opt }}$ (best match) and because physiologically it seems like a reasonable time frame to use for this purpose (Gunderson et al., 2010; Robakowski et al., 2012).

\section{Contributions of stomatal function to photosynthetic rates}

It is important to note that our measures of photosynthetic rates at $T_{\text {opt }}\left(A_{\text {opt }}\right)$ were generally made $3-4$ hours after leaves were detached from trees, and although we kept them hydrated in floral water pik tubes, it was possible that stomatal conductance rates, and consequently $A_{\text {opt, }}$, were negatively affected by leaf detachment. Thus, we compared rates of $A_{\text {opt }}$ reported here with rates of photosynthesis measured under optimal in situ conditions within our experimental plots and found that the two were significantly correlated (and close to $1:$ 1) (Figure S1). In addition, increased vapor pressure deficit (VPD) at higher temperatures can limit stomatal conductance rates, reducing intercellular $\mathrm{CO}_{2}$ concentrations $\left(\mathrm{C}_{\mathrm{i}}\right)$ and photosynthetic rates $(A)$ independent of biochemical effects (Zhang et al., 2001; Hikosaka et al., 2006). Therefore, we examined relationships of leaf diffusive conductance and $C_{i}$ to leaf temperatures (Figures S2 and S3). The relationship of leaf conductance to temperature roughly matched that of photosynthesis (compare Figure S2 to S4), although conductance appears to peak at cooler temperatures. Moreover, because in most species, $\mathrm{C}_{\mathrm{i}}$ was not lower (and often higher) at the highest temperature $\left(37^{\circ} \mathrm{C}\right)$ than at $32{ }^{\circ} \mathrm{C}$, it is unlikely that stomatal closure is responsible for low photosynthetic rates at $37^{\circ} \mathrm{C}$. To more formally address the possible effect of low humidity and high VPD, we followed the procedure of Gunderson et al. (2010). Dividing our measures of $A$ by $C_{\mathrm{i}}$ and plotting against temperature revealed nonstomatal decreases in $A$ (Zhang et al., 2001) (Figure S5), and plots with peaks that generally match those of absolute photosynthesis. In other words, the rate of $A$ per unit $\mathrm{CO}_{2}$ declined at high temperatures, indicating that decreasing $C_{i}$ caused by stomatal closure is not the singular cause of the decline in $A$ above $T_{\mathrm{opt}} ;$ and the shapes 
of the curves suggest stomatal closure is not the dominant cause - but that there must also be biochemical limitations such as changes in expression and activation of photosynthetic enzymes or leaky membranes (Schrader et al., 2004; Sage \& Kubien, 2007). Moreover, analyses that used only air temperatures from $12{ }^{\circ} \mathrm{C}$ to $32{ }^{\circ} \mathrm{C}$ came to similar conclusions as those using the entire curve. The comparison to in situ field measurements and consideration of changes in $A / C_{i}$ vs. temperature suggest our measurements provide a reasonable estimate of temperature optima of photosynthesis for the studied plants.

\section{Statistical analysis}

Mixed effects analyses of variance (ANOVAs) were used to compare photosynthetic temperature optimum $\left(T_{\text {opt }}\right)$, the photosynthetic rate at $T_{\text {opt }}\left(A_{\text {opt }}\right)$, and the $b$ parameter that describes the spread of response curves. Models included the following independent variables: site, species (or southern range limit), overstory condition, warming treatment, and all 2- and 3-way interactions among variables. Plot was added to each model as a random effect with each plot having a unique identifying number. Models were run separately by year since different subsets of species were measured each year (cf. Table 4), but additional models were run across years for a subset of species (Acer rubrum, Betula papyrifera and Populus tremuloides) (Tables S1, S2, and S3). These included year and campaign (early, mid, and late summer), in addition to the independent variables listed above to determine whether treatment effects on these species grew stronger or weaker from year to year or seasonally within years. Results of analyses including southern (lower latitude) range limit as a main effect are shown in the appendix (Tables S4, S5, and S6) but not in the main text as the results are similar to analyses using species as a main effect.

In 2009, two kinds of models were run since three of the seven species were measured at one site only (Table 5). In all cases, we used the fullest model possible, meaning that some species groups were included in more than one analysis (e.g.,
A. rubrum individuals were included in the analysis of species measured at both sites, and the individuals measured in Cloquet were also included in the analysis of species measured at Cloquet only). We added several measures of plotlevel temperature and soil volumetric water content data (i.e., averaged over the week prior to the measurement date or by field season) as covariates to this model to see if variation in temperatures within treatments among sites, habitats, or years further explained responses beyond 'treatment' as a nominal variable. None of these covariates was significant, so we interpret treatment effects as largely similar across all of these sources of variation and present models without temperature or soil water covariates included (Tables S1, S2, and S3). All statistical analyses were conducted in JMP statistical analysis software (JMP 10.0, SAS Institute, Cary, NC, USA). See Table 2 for a summary of analyses and where they are shown in the manuscript.

\section{Results}

\section{Response of $T_{\text {opt }}$ to the warming treatment}

To determine whether there was evidence that acclimation to the warming treatment differed among years or seasonally within years, we used data for three species; Acer rubrum, Betula papyrifera, and Populus tremuloides (Table 4 ). These species were measured in all years and all campaigns (early, mid, and late summer). We found that absolute photosynthetic temperature optima $\left(T_{\text {opt }}\right)$ varied among years, likely due at least in part to yearly variability in ambient temperatures, but the effect of the warming treatment on $T_{\text {opt }}$ was similar for all three species in all years and campaigns as evidenced by the lack of treatment interactions (Table S1). As comparisons of the three species among years provide no evidence that plant responses to warming differed across campaigns

Table 4 Summary of species measured by year and site, as well as statistical analyses. Each analysis shown was run three times to test for differences in photosynthetic temperature optima $\left(T_{\text {opt }}\right)$, photosynthetic rates at $T_{\text {opt }}\left(A_{\text {opt }}\right)$ and the parameter that describes the spread of the response curves $(b)$. The solid box represents analyses run among years for the three species measured most often (Tables S1, S2, and S3). The dashed boxes represent analyses run within year for all species measured at both sites (Tables 5-7). The asterisks ${ }^{*}$ ) shown represent a second set of analyses run in 2009 which included only measurements made at the Cloquet site (Table 5). Tables S4, S5, and S6 show results substituting southern (lower latitude) range limit for species in the statistical models

\begin{tabular}{|c|c|c|c|c|c|c|}
\hline \multirow[b]{2}{*}{ Year } & \multicolumn{6}{|l|}{ Species } \\
\hline & Betula papyrifera & Populus tremuloides & Acer rubrum & Acer saccharum & Quercus rubra & Quercus macrocarpa \\
\hline 2009 & $\mathrm{C}^{*}, \mathrm{E}$ & $\mathrm{C}^{*}, \mathrm{E}$ & $\mathrm{C}^{*}, \mathrm{E}$ & I & $C^{*},-$ & $\mathrm{C}^{*},-$ \\
\hline 2010 & $\mathrm{C}, \mathrm{E}$ & $\bar{C}, \bar{E}$ & $\bar{C}, \bar{E}$ & 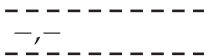 & $\bar{C}, \bar{E}----$ । &,-- \\
\hline 2011 & $\bar{C}, \bar{E}$ & $\bar{C}, \bar{E}$ & $\bar{C}, \bar{E}$ & $\mathrm{C}, \mathrm{E}$ & $\mathrm{C}, \mathrm{E}$ & $\bar{C}, \bar{E}$ \\
\hline
\end{tabular}

C, measured at the Cloquet site; E, measured at the Ely site; -, not measured. 
Table 5 Mixed effect ANOva results for measurements made in 2009. Two analyses were run since two of the species were measured at one site only. $P<0.05$ are indicated in bold; $P<0.10$ are italicized

\begin{tabular}{|c|c|c|c|c|c|c|c|}
\hline \multirow[b]{2}{*}{ Species } & \multirow[b]{2}{*}{ Source of variance } & \multicolumn{2}{|l|}{$T_{\text {opt }}$} & \multicolumn{2}{|l|}{$A_{\mathrm{opt}}$} & \multicolumn{2}{|l|}{$b$} \\
\hline & & $F$ & $P$-value & $F$ & $P$-value & $F$ & $P$-value \\
\hline (both sites) & Site & 8.12 & 0.008 & 5.79 & 0.022 & 1.94 & 0.177 \\
\hline A. rubrum & Species & 4.24 & 0.006 & 91.81 & $<0.001$ & 41.31 & $<0.001$ \\
\hline A. saccharum & Overstory condition & 18.70 & $<0.001$ & 38.99 & $<0.001$ & 13.54 & 0.001 \\
\hline B. papyrifera & Warming & 17.28 & $<0.001$ & 5.34 & 0.027 & 7.91 & 0.010 \\
\hline \multirow[t]{10}{*}{ P. tremuloides } & Site $\times$ Species & 1.44 & 0.231 & 2.73 & 0.045 & 1.48 & 0.220 \\
\hline & Site $\times$ Overstory Condition & 0.48 & 0.495 & 0.01 & 0.938 & 0.05 & 0.832 \\
\hline & Site $\times$ Warming & 1.07 & 0.310 & 0.11 & 0.746 & 0.10 & 0.756 \\
\hline & Species $\times$ Overstory condition & 5.48 & 0.001 & 5.86 & $<0.001$ & 12.02 & $<0.001$ \\
\hline & Species $\times$ Warming & 0.81 & 0.490 & 0.33 & 0.802 & 1.10 & 0.352 \\
\hline & Overstory condition $\times$ Warming & 1.40 & 0.245 & 0.09 & 0.770 & 0.94 & 0.341 \\
\hline & Site $\times$ Species $\times$ Overstory & 1.83 & 0.143 & 0.68 & 0.568 & 3.11 & 0.028 \\
\hline & Site $\times$ Species $\times$ Warming & 1.02 & 0.387 & 0.27 & 0.848 & 1.57 & 0.197 \\
\hline & Site $\times$ Overstory $\times$ Warming & 0.23 & 0.636 & 6.57 & 0.016 & 5.02 & 0.036 \\
\hline & Species $\times$ Overstory $\times$ Warming & 1.37 & 0.254 & 1.57 & 0.199 & 4.10 & 0.008 \\
\hline (Cloquet only) & Species & 2.88 & 0.018 & 32.27 & $<0.001$ & 15.10 & $<0.001$ \\
\hline A. rubrum & Overstory condition & 6.69 & 0.016 & 20.93 & $<0.001$ & 12.18 & 0.003 \\
\hline A. saccharum & Warming & 9.90 & 0.006 & 1.30 & 0.273 & 0.27 & 0.608 \\
\hline B. papyrifera & Species $\times$ Overstory condition & 1.45 & 0.211 & 2.34 & 0.047 & 7.32 & $<0.001$ \\
\hline P. tremuloides & Species $\times$ Warming & 0.75 & 0.585 & 0.15 & 0.978 & 0.21 & 0.959 \\
\hline Q. macrocarpa & Overstory condition $\times$ Warming & 2.37 & 0.138 & 1.04 & 0.326 & 1.08 & 0.314 \\
\hline Q. rubra & Species $\times$ Overstory $\times$ Warming & 1.53 & 0.188 & 1.31 & 0.267 & 1.92 & 0.097 \\
\hline
\end{tabular}

Dependent variables: $T_{\mathrm{opt}}$ - photosynthetic temperature optimum, $A_{\mathrm{opt}}-$ rate of $\mathrm{CO}_{2}$ assimilation measured at $T_{\mathrm{opt}}$, $b-$ a unitless parameter describing the spread of each temperature response curve.

Table 6 Mixed effect ANOvA results for measurements made in 2010. $P<0.05$ are indicated in bold; $P<0.10$ are italicized

\begin{tabular}{|c|c|c|c|c|c|c|c|}
\hline \multirow[b]{2}{*}{ Species } & \multirow[b]{2}{*}{ Source of variance } & \multicolumn{2}{|l|}{$T_{\mathrm{opt}}$} & \multicolumn{2}{|l|}{$A_{\mathrm{opt}}$} & \multicolumn{2}{|l|}{$b$} \\
\hline & & $F$ & $P$-value & $F$ & $P$-value & $F$ & $P$-value \\
\hline A. rubrum & Site & 10.42 & 0.004 & 67.53 & $<0.001$ & 20.16 & $<0.001$ \\
\hline A. saccharum & Species & 22.76 & $<0.001$ & 62.90 & $<0.001$ & 9.85 & $<0.001$ \\
\hline B. papyrifera & Overstory condition & 1.90 & 0.181 & 112.06 & $<0.001$ & 21.53 & $<0.001$ \\
\hline P. tremuloide & Warming & 11.15 & 0.003 & 0.58 & 0.451 & 0.36 & 0.550 \\
\hline Q. macrocarpa & Site $\times$ Species & 1.41 & 0.242 & 0.87 & 0.458 & 0.67 & 0.578 \\
\hline \multirow[t]{9}{*}{ Q.rubra } & Site $\times$ Overstory condition & 2.21 & 0.150 & 0.46 & 0.506 & 0.04 & 0.849 \\
\hline & Site $\times$ Warming & 0.03 & 0.857 & 1.26 & 0.271 & 0.30 & 0.588 \\
\hline & Species $\times$ Overstory condition & 2.93 & 0.035 & 3.78 & 0.011 & 1.71 & 0.166 \\
\hline & Species $\times$ Warming & 1.76 & 0.155 & 2.14 & 0.097 & 0.33 & 0.803 \\
\hline & Overstory condition $\times$ Warming & 0.17 & 0.680 & 1.83 & 0.188 & 1.53 & 0.225 \\
\hline & Site $\times$ Species $\times$ Overstory & 0.87 & 0.456 & 1.12 & 0.342 & 0.76 & 0.521 \\
\hline & Site $\times$ Species $\times$ Warming & 0.22 & 0.880 & 2.60 & 0.053 & 3.04 & 0.030 \\
\hline & Site $\times$ Overstory $\times$ Warming & 0.01 & 0.942 & 0.56 & 0.463 & 0.02 & 0.899 \\
\hline & Species $\times$ Overstory $\times$ Warming & 0.22 & 0.885 & 1.52 & 0.209 & 2.13 & 0.097 \\
\hline
\end{tabular}

Dependent variables: $T_{\mathrm{opt}}$ - photosynthetic temperature optimum, $A_{\mathrm{opt}}-$ rate of $\mathrm{CO}_{2}$ assimilation measured at $T_{\mathrm{opt}}$, $b-$ a unitless parameter describing the spread of each temperature response curve.

within a year or among years of the experiment, in the remaining within-year analyses we compared as many of the six species as were measured in each year, pooling across campaigns (Table 4).
In each year, species differed in $T_{\mathrm{opt}}$, but the rankings of $T_{\text {opt }}$ were not related to climate of origin, rejecting H1 (Tables 5-7, Fig. 1). For example, temperate species had both the lowest and highest $T_{\text {opt }}$ in 2009 (Fig. 1). 
Table 7 Mixed effect ANOva results for measurements made in 2011. $P<0.05$ are indicated in bold; $P<0.10$ are italicized

\begin{tabular}{|c|c|c|c|c|c|c|c|}
\hline \multirow[b]{2}{*}{ Species } & \multirow[b]{2}{*}{ Source of variance } & \multicolumn{2}{|l|}{$T_{\text {opt }}$} & \multicolumn{2}{|l|}{$A_{\mathrm{opt}}$} & \multicolumn{2}{|l|}{$b$} \\
\hline & & $F$ & $P$-value & $F$ & $P$-value & $F$ & $P$-value \\
\hline A. rubrum & Site & 8.33 & 0.006 & 26.94 & $<0.001$ & 14.51 & $<0.001$ \\
\hline A. saccharum & Species & 6.99 & $<0.001$ & 36.95 & $<0.001$ & 1.98 & 0.082 \\
\hline B. papyrifera & Overstory condition & 2.75 & 0.104 & 83.10 & $<0.001$ & 3.13 & 0.083 \\
\hline P. tremuloide & Warming & 5.65 & 0.022 & 0.58 & 0.454 & 0.32 & 0.573 \\
\hline Q. macrocarpa & Site $\times$ Species & 4.08 & 0.001 & 2.07 & 0.069 & 1.28 & 0.272 \\
\hline \multirow[t]{9}{*}{ Q.rubra } & Site $\times$ Overstory condition & 0.85 & 0.362 & 0.41 & 0.525 & 1.17 & 0.284 \\
\hline & Site $\times$ Warming & 0.03 & 0.868 & 3.47 & 0.074 & 2.12 & 0.151 \\
\hline & Species $\times$ Overstory condition & 2.18 & 0.056 & 6.01 & $<0.001$ & 2.11 & 0.063 \\
\hline & Species $\times$ Warming & 0.46 & 0.804 & 0.90 & 0.484 & 2.74 & 0.019 \\
\hline & Overstory condition $\times$ Warming & 0.31 & 0.583 & 0.20 & 0.655 & 3.66 & 0.061 \\
\hline & Site $\times$ Species $\times$ Overstory & 1.17 & 0.324 & 0.74 & 0.594 & 1.51 & 0.184 \\
\hline & Site $\times$ Species $\times$ Warming & 0.65 & 0.661 & 0.41 & 0.840 & 2.12 & 0.063 \\
\hline & Site $\times$ Overstory $\times$ Warming & 0.03 & 0.857 & 0.08 & 0.775 & 0.40 & 0.528 \\
\hline & Species $\times$ Overstory $\times$ Warming & 0.21 & 0.958 & 0.83 & 0.531 & 1.60 & 0.158 \\
\hline
\end{tabular}

Dependent variables: $T_{\mathrm{opt}}$ - photosynthetic temperature optimum, $A_{\mathrm{opt}}$ - rate of $\mathrm{CO}_{2}$ assimilation measured at $T_{\mathrm{opt}}$, $b-$ a unitless parameter describing the spread of each temperature response curve.

There was a consistent acclimation of $T_{\mathrm{opt}}$ with $T_{\mathrm{opt}}$ shifting upward with warming ( $P$-value of the treatment effect was significant in each case) in each year $x$ 'measured species set' combination (Tables 4-7; Fig. 1). These responses were similar across all species, sites, and overstory conditions as evidenced by the lack of warming treatment interactions in statistical results, consistent with $\mathrm{H} 2 \mathrm{a}$, but rejecting $\mathrm{H} 2 \mathrm{~b}$ (Tables 5-7). The general trend was for species to adjust their $T_{\text {opt }}$ upward in response to the warming treatment by an average of $1.1 \pm 0.21^{\circ} \mathrm{C}$ (species-level average across all years, Fig. 1). For all species measured in each year, the mean shift for all species was slightly lower in 2011 $\left(0.88 \pm 0.12{ }^{\circ} \mathrm{C}\right)$ than in $2009\left(1.17 \pm 0.31{ }^{\circ} \mathrm{C}\right)$ or 2010 $\left(1.38 \pm 0.26^{\circ} \mathrm{C}\right)$. However, the degree of midday warming trees were exposed to in $2011\left(2.6 \pm 0.01{ }^{\circ} \mathrm{C}\right)$ was also lower than that in 2009 and 2010 (3.1 $\pm 0.01{ }^{\circ} \mathrm{C}$ above ambient in both years).

\section{Response of $A_{\text {opt }}$ and the $b$ parameter to the warming treatment}

The photosynthetic rate measured at $T_{\text {opt }}\left(A_{\text {opt }}\right)$ of all species was unaffected by the warming treatment in most cases (Tables 5-7; Fig. 2). This result rejects H3, both because we did not observe a negative impact of warming on $A_{\text {opt }}$ (due to temperatures exceeding $T_{\text {opt }}$ ) and because boreal and temperate species were similarly affected. In 2009, $A_{\text {opt }}$ of the two boreal and two temperate species measured at the Cloquet site showed a positive response to the warming treatment (Table 5; Fig. 2). This result also rejects $\mathrm{H} 3$, again because all species responded similarly and because $A_{\text {opt }}$ was positively affected by warming. Leaf nitrogen and specific leaf area were unaffected by the temperature treatments (data not shown).

Despite the general lack of warming treatment effects on $A_{\text {opt }}$, there were significant species differences in $A_{\text {opt }}$ in all years that corresponded to species' successional status. Averaged across years and overstory conditions, shade tolerant and midtolerant species such as Acer saccharum and A. rubrum exhibited the lowest rates of $A_{\text {opt }}$ (3.4-5.7 $\left.\mu \mathrm{mol} \mathrm{m}{ }^{-2} \mathrm{~s}^{-1}\right)$, while light-demanding species such as Betula papyrifera and Populus tremuloides had rates that were two to three times higher on average (9.4-11.1 $\mu \mathrm{mol} \mathrm{m}{ }^{-2} \mathrm{~s}^{-1}$ ). These rates of $A_{\text {opt }}$ are significantly correlated (and slightly lower, but close to the $1: 1$ line) with light-saturated photosynthetic rates measured in situ (on attached leaves) in the experimental plots as part of our larger experiment (Figure S1).

The $b$ parameter also differed significantly among species (Tables 5-7; Fig. 3), with the two Acer species having the smallest $b$ in all years. This indicates a lower temperature sensitivity and a broader optimal range. $A$. saccharum and $A$. rubrum had $b$ values that averaged $0.017 \pm 0.001$, whereas the two Quercus species, B. papyrifera, and $P$. tremuloides all averaged $0.028 \pm 0.001$ across treatments and years. The $b$ parameter was affected by the warming treatment in a few cases (i.e., warming increased $b$ for B. papyrifera in 2009 and for $P$. tremuloides in 2011), but these results appeared to be minor and had negligible effects on photosynthetic rates.

\section{Acclimation response to temperature history}

In general, the $T_{\mathrm{opt}}$ of ambient and warmed plants was close to but not perfectly matched to recent 

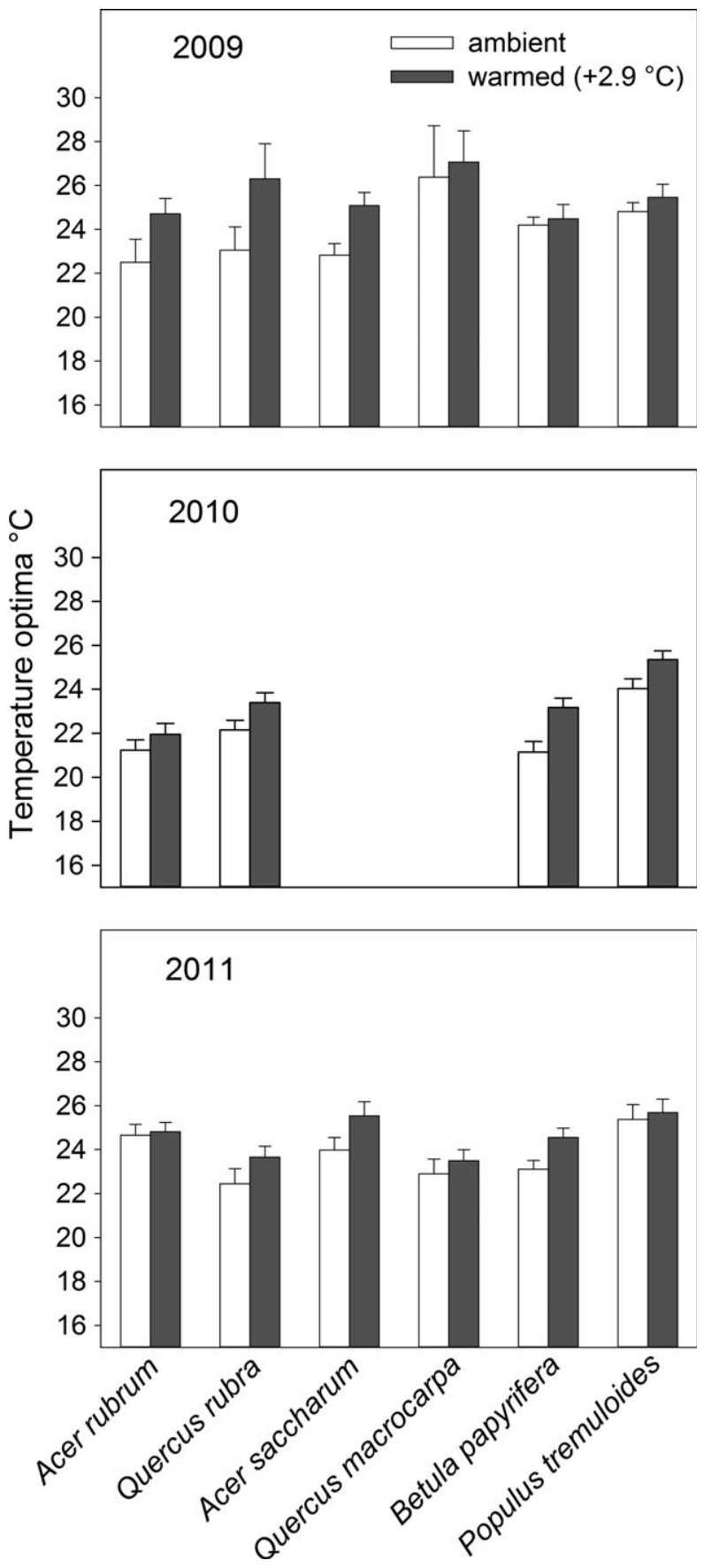

Fig. 1 Mean temperature optima $\left(T_{\mathrm{opt}} \pm \mathrm{SE}\right)$ for juvenile trees of four temperate and two boreal species grown at two temperatures, ambient and $2.9 \pm 0.01{ }^{\circ} \mathrm{C}$ above ambient. Species are shown in order of their southern (lower latitude) range limits, with the most southern species on the left. A. saccharum and Q. macrocarpa were not measured in 2010. $T_{\text {opt }}$ estimates were averaged for individuals growing in open and closed plots. $T_{\text {opt }}$ was estimated from temperature response curves.

temperatures. Under closed canopy conditions, $T_{\text {opt }}$ in both temperature treatments best matched maximum recent temperatures, while $T_{\text {opt }}$ of ambient and warmed

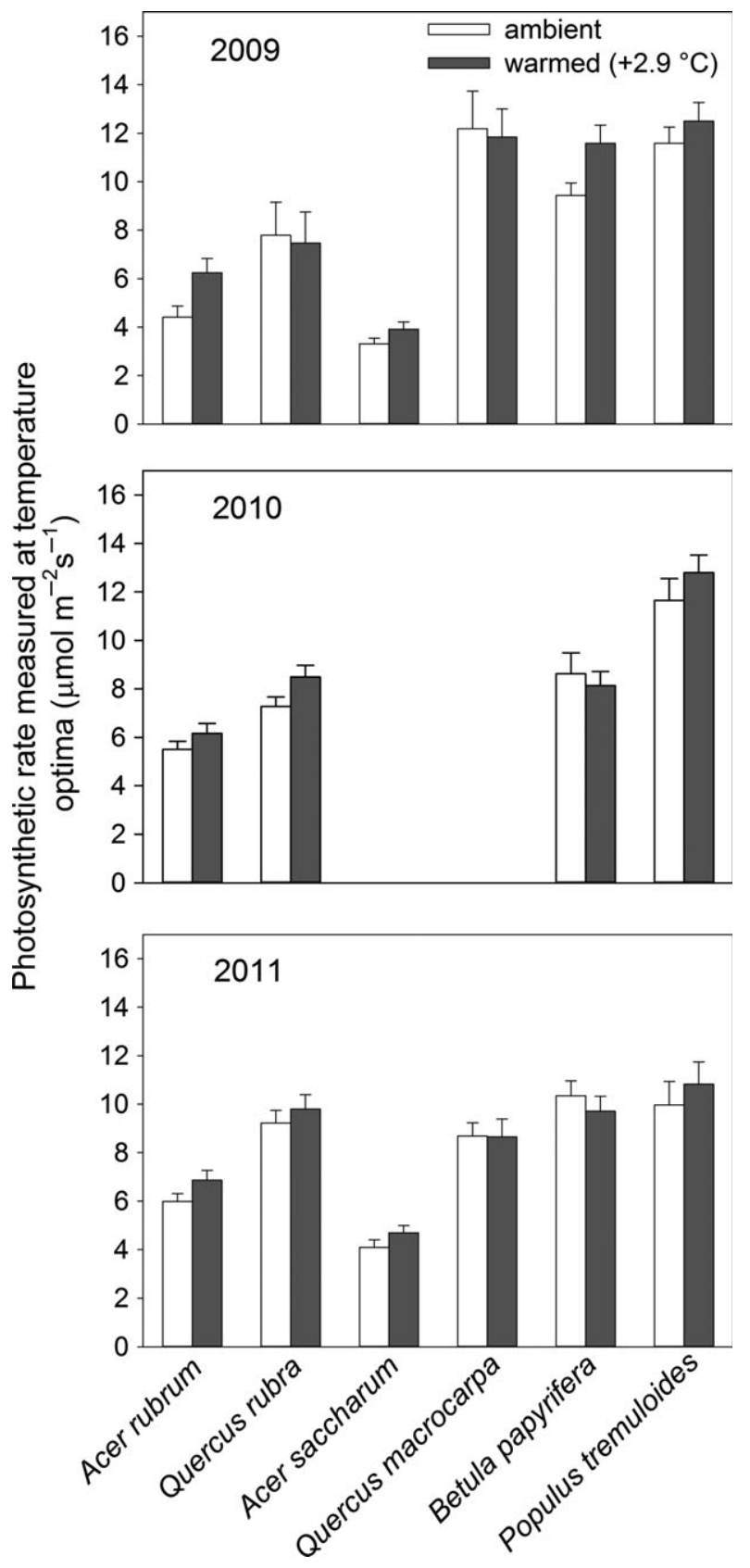

Fig. 2 Mean maximum photosynthetic rates $\left(A_{\text {opt }} \pm \mathrm{SE}\right)$ for juveniles trees of four temperate and two boreal species grown at two temperature, ambient and $2.9 \pm 0.01{ }^{\circ} \mathrm{C}$ above ambient. Species are shown in order of their southern (lower latitude) range limits, with the most southern species on the left. A. saccharum and Q. macrocarpa were not measured in 2010. $A_{\text {opt }}$ estimates were averaged for individuals growing in open and closed plots. $A_{\text {opt }}$ was measured at the photosynthetic temperature optima of temperature response curves.

plants in the open best matched mean midday temperatures (Figs 4 and 5). Similar trends were observed when these comparisons were made by year, species, or time 

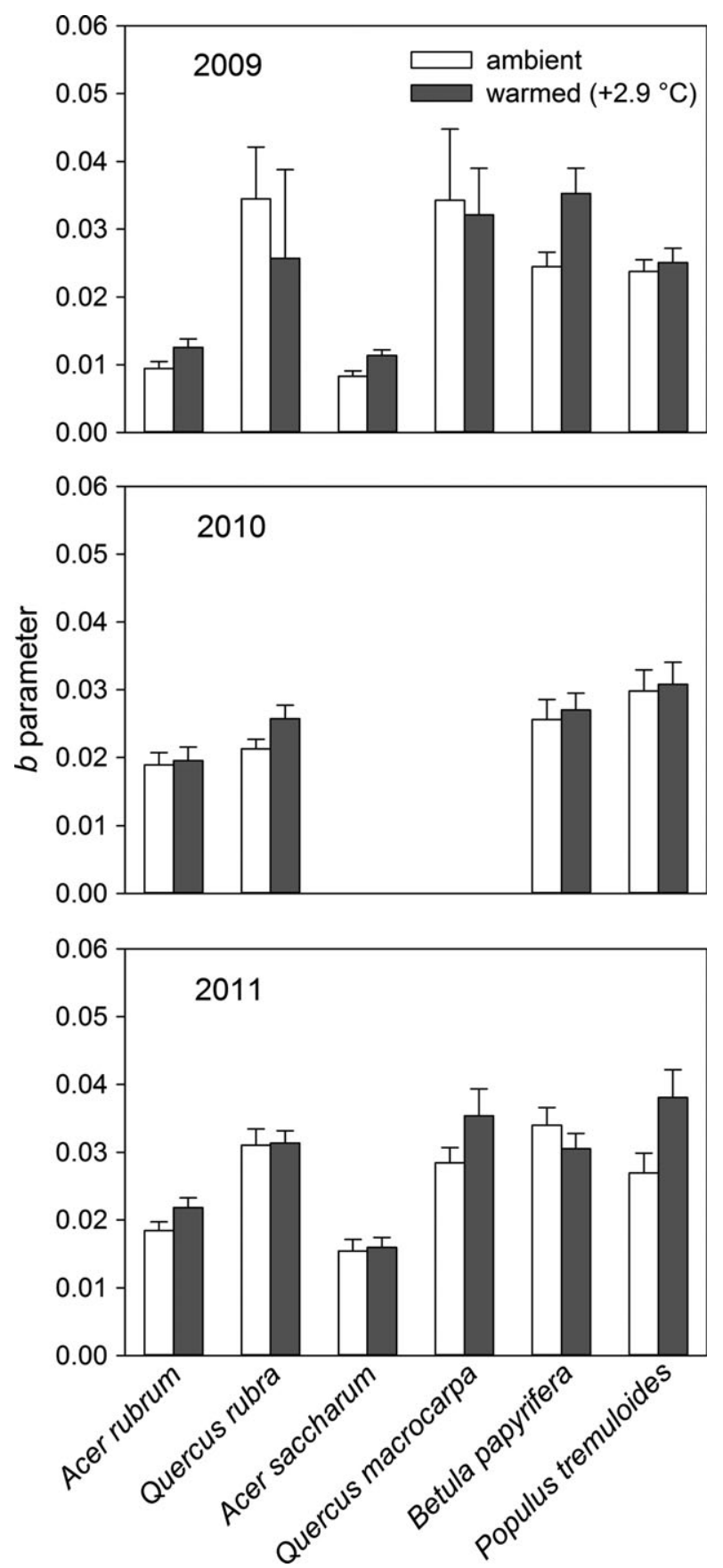

Fig. 3 Mean value of unitless $b$ parameter (which denotes the shape of the temperature response curve, \pm SE) for juveniles trees of four temperate and two boreal species grown at two temperature, ambient and $2.9 \pm 0.01{ }^{\circ} \mathrm{C}$ above ambient. Species are shown in order of their southern (lower latitude) range limits, with the most southern species on the left. A. saccharum and $Q$ macrocarpa were not measured in 2010. The $b$ parameters were averaged for individuals growing in open and closed plots.

of year (Tables S7-S9). Thus, despite showing only a $1.1 \pm 0.21{ }^{\circ} \mathrm{C}$ difference in mean $T_{\text {opt }}$ between ambient and warmed plants (for a $2.9 \pm 0.01{ }^{\circ} \mathrm{C}$ temperature difference), the $T_{\mathrm{opt}}$ of plants in the warmed treatment matched recent temperatures they experienced as closely as the $T_{\text {opt }}$ of plants in the ambient treatment matched their recent temperatures. In other words, using the degree of matching to experienced temperatures as a measure, the ambient and warmed treatment plants were equally well acclimated in terms of their photosynthetic optimas. Moreover, in both temperature treatments, $T_{\text {opt }}$ was at a level where realized photosynthesis was within $90-95 \%$ of optimal (Table 8).

\section{Discussion}

Documenting photosynthetic temperature responses and acclimation to changes in temperature provides critical information for projecting the impacts of climate change on ecological systems. In particular, acclimation could act to limit potential reductions in gas-exchange rates (Berry \& Bjorkman, 1980; Kattge \& Knorr, 2007; Gunderson et al., 2010) associated with higher growth temperatures. Such information can enhance ecosystem carbon balance models by representing climate change responses more accurately. All six species consistently showed acclimation responses to warming. These acclimation responses were robust across years, canopy conditions, and species differences in tolerance (to shade and drought) and in geographic distribution. Moreover, we found that acclimation in plants grown under warmer temperatures served to match $T_{\text {opt }}$ to prevailing temperatures as well as did ambient plants. $T_{\text {opt }}$ under both ambient and warmed conditions was not perfectly matched to the range of experienced temperatures, but was close (average $\approx 90-95 \%$ the photosynthesis that would occur with a perfect $T_{\text {opt }}$ match to recent midday temperatures).

\section{Acclimation potential of $T_{\text {opt }}$ to warming}

Acclimation of photosynthesis has been shown in leaves formed at one growth temperature and later exposed to different temperatures (i.e., leaves formed in cool spring temperatures and later exposed to warmer midsummer temperatures) (Loveys et al., 2003; Gunderson et al., 2010), though some research suggest that full acclimation requires that leaves are formed at the new growth temperature (Veres \& Williams, 1984; Atkin et al., 2006). Our results documented an acclimation response (a $1.1 \pm 0.21{ }^{\circ} \mathrm{C}$ shift in $T_{\text {opt }}$ on average) to a temperature increase that roughly approximated regional predictions of climate change.

There are contrasting ways one can view these results. Compared with the $2.9 \pm 0.01{ }^{\circ} \mathrm{C}$ mean difference in daytime temperatures, it appears that plants did not fully acclimate to the warmer temperature 
Table 8 Mean \pm SE percent of photosynthetic rate at $T_{\text {opt }}$ at prevailing 5 days temperatures under ambient and $2.9 \pm 0.01{ }^{\circ} \mathrm{C}$ warming by canopy condition

Percent of photosynthetic rate at $T_{\text {opt }}$ at prevailing 5 days temperatures

\begin{tabular}{llll}
\hline Open & & \multicolumn{2}{l}{ Closed } \\
Ambient & Warmed & & Ambient \\
& & & Warmed \\
$97 \pm 0.8$ & $96 \pm 0.8$ & $89 \pm 1.2$ & $94 \pm 0.8$ \\
$95 \pm 1.2$ & $95 \pm 0.6$ & $92 \pm 1.2$ & $95 \pm 0.8$ \\
$93 \pm 1.1$ & $92 \pm 1.3$ & $89 \pm 1.3$ & $92 \pm 1.1$ \\
$94 \pm 0.6$ & $94 \pm 0.6$ & $90 \pm 0.7$ & $93 \pm 0.6$
\end{tabular}

Species

$\begin{array}{lllll}\text { Acer rubrum } & 92 \pm 1.8 & 94 \pm 1.3 & 93 \pm 1.1 & 94 \pm 0.9 \\ \text { Acer saccharum } & 96 \pm 1.3 & 93 \pm 1.8 & 89 \pm 2.9 & 93 \pm 1.7 \\ \text { Betula papyrifer } & 97 \pm 0.6 & 94 \pm 1.1 & 90 \pm 1.4 & 94 \pm 1.0 \\ \text { Populus tremuloides } & 93 \pm 1.3 & 95 \pm 1.3 & 86 \pm 2.2 & 90 \pm 2.2 \\ \text { Quercus macrocarpa } & 91 \pm 3.1 & 93 \pm 4.2 & 85 \pm 3.8 & 91 \pm 2.8 \\ \text { Quercus rubrum } & 95 \pm 1.8 & 94 \pm 1.8 & 93 \pm 1.3 & 95 \pm 1.1 \\ & & & & \\ \text { Campaign } & 93 \pm 1.3 & 91 \pm 1.5 & 92 \pm 1.2 & 93 \pm 1.0 \\ \text { Early summer } & 98 \pm 0.5 & 95 \pm 0.7 & 93 \pm 0.9 & 96 \pm 0.5 \\ \text { Midsummer } & 94 \pm 1.1 & 95 \pm 0.8 & 86 \pm 1.5 & \\ \text { Late summer } & & & \end{array}$
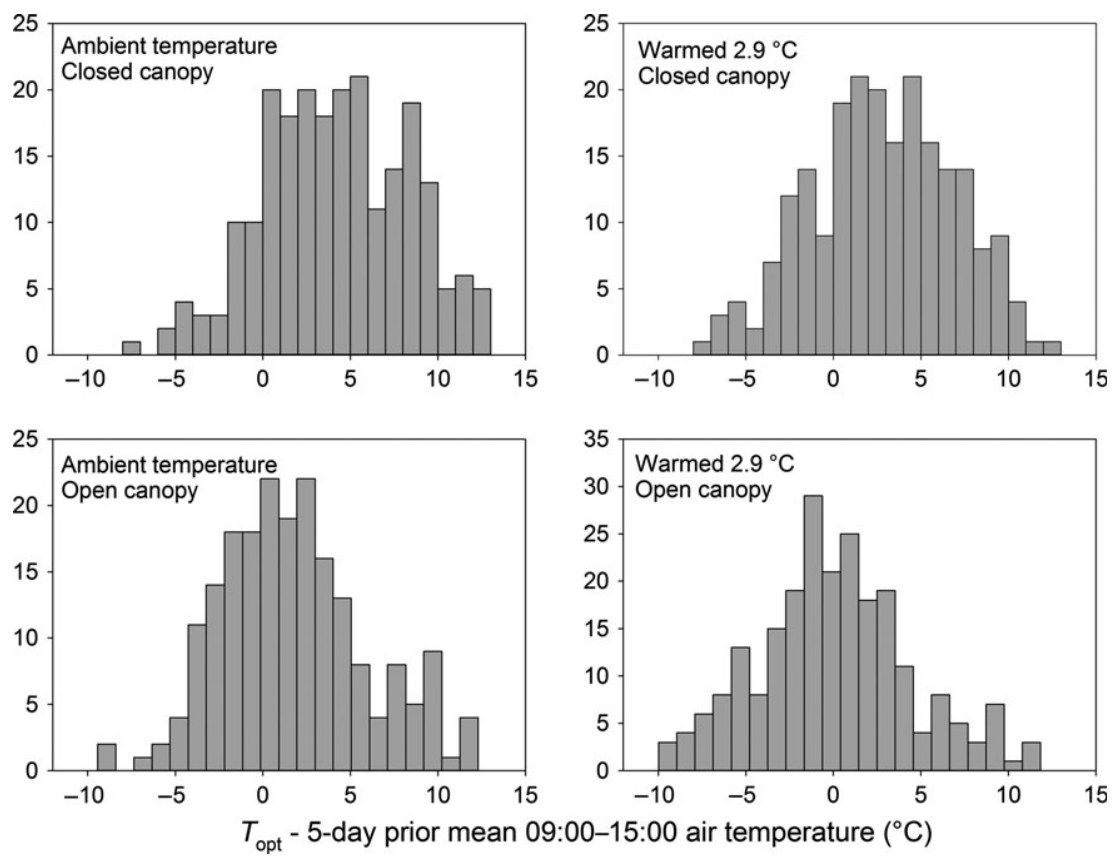

Fig. 4 The distribution of photosynthetic temperature optima $\left(T_{\mathrm{opt}}\right)$ minus the 5 days prior mean air temperature during the measurement period (09:00-15:00 hours) under open and closed canopy and ambient and warmed $2.9 \pm 0.01{ }^{\circ} \mathrm{C}$ conditions.

treatment. This interpretation assumes that $T_{\text {opt }}$ under ambient conditions was very well matched to recent temperature experienced by the plants. This was not the case. Although the $T_{\text {opt }}$ of ambient plants was relatively well matched to recently experienced temperatures, they were no better matched than the $T_{\text {opt }}$ of 

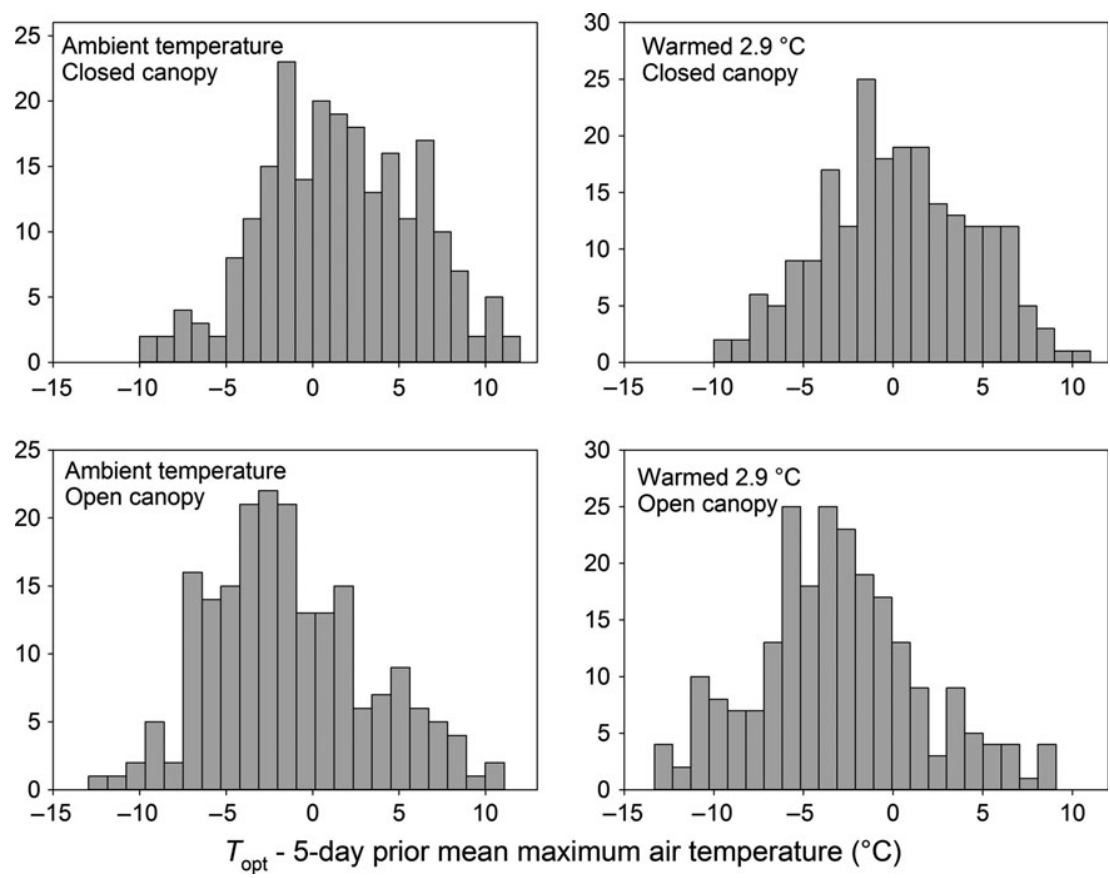

Fig. 5 The distribution of photosynthetic temperature optima $\left(T_{\mathrm{opt}}\right)$ minus the 5 days prior maximum air temperature under open and closed canopy and ambient and warmed $2.9 \pm 0.01{ }^{\circ} \mathrm{C}$ conditions.

warmed plants. For example, the mean $T_{\mathrm{opt}}$ of warmed plants under open canopy conditions was $24.0^{\circ} \mathrm{C}$ in 2009, $23.1^{\circ} \mathrm{C}$ in 2010 , and $24.3^{\circ} \mathrm{C}$ in 2011 , while 5 days prior mean temperatures were $24.1^{\circ} \mathrm{C}, 23.8^{\circ} \mathrm{C}$, and $24.0^{\circ} \mathrm{C}$, respectively. In contrast, mean $T_{\text {opt }}$ for the ambient treatment under open canopy conditions was $23.4^{\circ} \mathrm{C}$ in $2009,22.1{ }^{\circ} \mathrm{C}$ in 2010 , and $23.5^{\circ} \mathrm{C}$ in 2011 , while 5 day prior mean temperatures were $21.6^{\circ} \mathrm{C}$, $21.3{ }^{\circ} \mathrm{C}$, and $21.0^{\circ} \mathrm{C}$, respectively. Moreover, in both warming treatments, $T_{\text {opt }}$ was close enough to realized temperatures that realized photosynthesis was within 90-95\% of optimal (Table 8) because the shape of the photosynthesis-temperature response curve is not sharply peaked.

To determine whether leaves operate near their maximum capacity throughout the growing season (rather than just on average), we also compared $T_{\text {opt }}$ to prior mean temperatures in early, mid-, and late summer and found that seasonal temperature differences (which themselves were modest and only varied by approximately $\pm 4{ }^{\circ} \mathrm{C}$ ) did not have a significant effect on $T_{\mathrm{opt}}$ overall (Table S9). This suggests that seedlings of all species in both warming treatments, in both canopy conditions, and across the growing season were close to optimizing photosynthetic temperature responses; and warmed-treatment plants were as effective at doing this as plants growing under ambient conditions. Viewed from this perspective, regardless of only a $1.1{ }^{\circ} \mathrm{C}$ difference in $T_{\text {opt }}$ among warming treatments, acclimation to warming was highly effective, as warmed plants came as close to optimizing photosynthesis (in terms of temperature) as the unheated ambient plants. We argue that this perspective is the more reasonable one, as there was no evidence (and no a priori theory) that ambient plants under current conditions would have $T_{\text {opt }}$ that guaranteed photosynthetic rates to be near $100 \%$ of those possible.

\section{Species and interannual differences in $T_{\text {opt }}$ and acclimation potential}

We found that acclimation capacities (measured as the difference in $T_{\text {opt }}$ between ambient and warmed treatments) were statistically similar across all years for three species and among all species in each year, contrary to our hypothesis (H1) that boreal species would have limited acclimation capacities relative to temperate species. We made this prediction based on the idea that species growing near their warmer, lower latitude range limits where boundaries are determined in part by thermal limitations (Berry \& Bjorkman, 1980; Tjoelker et al., 1998; Gunderson et al., 2000; Davis \& Shaw, 2001) or increased levels of competition (Woodward, 1987) may be constrained in their potential to acclimate to warming, whereas species growing near their colder, higher latitude range limits may respond more strongly to warming. Instead, our results suggest that local ecotypes may be similarly adapted to local temperatures in 
terms of their photosynthetic temperature sensitivity, and therefore each of the six species measured in this study, whether boreal or temperate, may have similar acclimation capacities. Whether this kind of local adaptation is common is not well understood, since the body of literature is limited and shows conflicting results. A few studies have found that $T_{\text {opt }}$ is related to climate of origin in both intra- (Robakowski et al., 2012) and interspecific comparisons (Hill et al., 1988; Cunningham \& Read, 2002), but others determined that there is no evidence for intra- (Teskey \& Will, 1999; Gunderson et al., 2000) or interspecific (Gunderson et al., 2010) adaptation of $T_{\text {opt }}$ to climatic distribution. The studies that found significant relationships either measured mature trees that had spent their entire lifespan in differing temperatures (Robakowski et al., 2012) or seedlings that were collected directly from broad latitudinal ranges (Hill et al., 1988; Cunningham \& Read, 2002). Studies finding no relation between $T_{\text {opt }}$ and climate of origin used seedlings purchased from commercial nurseries or propagated plants from seeds or root segments (Teskey \& Will, 1999; Gunderson et al., 2000, 2010), but it is unclear whether the young plants experienced differing temperature regimes prior to the start of the experiment.

The similar $T_{\text {opt }}$ and $T_{\text {opt }}$ acclimation capacities observed in boreal and temperate species could potentially be explained in part by leaf habit. It has been proposed that the degree of plasticity in temperature sensitivity corresponds with the range of temperatures to which foliage is typically exposed (Berry \& Bjorkman, 1980; Read, 1990; Bunce, 2000). Each of the six species measured in the current study was winter deciduous and therefore exposed to similar temperature regimes given that leaf out of all species occurs within a narrow window of time in the spring. Consequently, leaves of all winter deciduous species may have similar $T_{\text {opts }}$ and may be limited in their ability to acclimate, leading to similar responses. A comparison with evergreen species, whose tissues are exposed to a much wider range of temperatures, would be necessary to test whether this holds true.

Because our study, along with most studies of photosynthetic acclimation potential (Hill et al., 1988; Battaglia et al., 1996; Teskey \& Will, 1999; Gunderson et al., 2000; Cunningham \& Read, 2002; Dillaway \& Kruger, 2010), measured juvenile trees, we are unsure whether the responses observed will translate to mature trees. Only Gunderson et al. (2010) made direct comparisons of acclimation potential for seedling-sapling size trees and mature trees. They found that tree size and age had no effect on acclimation responses of Quercus rubra (northern red oak) or Liquidambar styraciflua (sweetgum), suggesting that our results are similarly translatable.
We were unsure at the outset of this project whether relative differences in $T_{\text {opt }}$ between ambient and warmed plots would remain stable or change with time, as most studies looking at photosynthetic temperature acclimation were not long-term experiments and instead examined short-term responses following abrupt changes in air temperature (Cunningham \& Read, 2002; Ow et al., 2008; Gremer et al., 2012). We found that acclimation capacity was consistent across years and was slightly lower in 2011, likely because the degree of warming that trees were exposed to in that year was less than it had been in 2009 and 2010. The consistency in relative differences in $T_{\text {opt }}$ across years simplifies incorporating acclimation in ecosystem to global models to improve carbon balance algorithms.

\section{Parameter $b$ and $A_{\text {opt }}$}

The $b$ parameter characterizes sensitivity to short-term fluctuations in temperature, with a lower value indicating a broader response curve and less temperature sensitivity. The lowest values of $b$ of all the species in our study were in the two Acer species (Fig. 3), indicating that they may have inherently lower sensitivity to short-term temperature changes. Values of $b$ were also significantly lower in mid- and late summer as compared to early summer, suggesting that sensitivity to changing temperatures is more acute early in the growing season. Despite these differences in the shape of the temperature response curves, the Acer species were no more effective at optimizing photosynthetic rates (in terms of temperature) compared to the other species measured, nor were plants less effective at optimization in early summer (Table 8) or differentially responsive to warming in terms of $T_{\text {opt }}$ or $A_{\text {opt }}$ (Fig. 2). However, in contrast to the similar response of $T_{\text {opt }}$ or $A_{\text {opt }}$ to warming for the six species studied here, response of warming to in situ light-saturated net photosynthetic rates averaged across the entire growing season (including periods of non-optimal conditions) did differ for species with different climate origins, with rates increasing in temperate oaks and maples and decreasing in boreal species (Reich et al., 2015). All species in all years and times of year seemed to be able to acclimate and maintain $T_{\text {opt }}$ close enough to realized temperatures that realized photosynthesis was within 90 95\% of optimal. Nevertheless, rarely were plants in either temperature treatment completely acclimated to prevailing temperatures (Figs 4 and 5), indicating that the temperature responses of photosynthesis are broad enough that it is not necessary for these species to invest resources in keeping $T_{\text {opt }}$ fully acclimated to current temperatures. 


\section{Mechanisms of photosynthetic acclimation}

This study was designed to determine the extent that photosynthetic acclimation occurs in response to temperature changes similar to regional predictions of climate change, not to determine the underlying mechanisms of acclimation. Nonetheless, we can use published literature to make inferences about possible mechanisms. Models used to investigate the effect of climate warming on plant function often incorporate the Farquahar et al. (1980) model of $C_{3}$ photosynthesis (Medlyn et al., 2002a,b; Kattge \& Knorr, 2007). The Farquhar model has the potential to accurately characterize photosynthetic response to increased temperatures based on the acclimation response of the potential rate of electron transport $\left(J_{\max }\right)$ and the maximum rate of Rubisco activity $\left(V_{\text {cmax }}\right)$. Both parameters have been shown to acclimate to plant growth temperature and thus act to limit potential reductions in photosynthetic rates (Bernacchi et al., 2003; Onoda et al., 2005; Kositsup et al., 2009), but further research would be required to determine if this is the underlying cause of acclimation in our study.

Predicting future consequences of climate warming will require information on acclimation responses of photosynthesis, but we realize this is only one piece of the puzzle. Respiration rates of plants, soils, and microbes as well as nutrient cycling will also be modified by increasing temperatures, and will be affected indirectly by the decline in soil moisture that will likely accompany higher temperatures. Phenological responses such as earlier budbreak in the spring may increase growing season length, while potentially causing plant-herbivore asynchrony if herbivores respond differently to changes in climate as seen in B4WarmED (Schwartzberg et al., 2014). Assuming that these, or other, responses are species-specific, relative rates of growth and competitiveness may also change.

Most empirical succession models assume that future vegetation will follow shifts in climate (Davis \& Shaw, 2001) based on projected shifts in 'suitable' habitats (Iverson \& Prasad, 1998), defined by the climate envelope of each species. These models sometimes predict considerable changes in species distributions, including poleward migrations and species eliminations from the warmest parts of a range (Pastor \& Post, 1988; Schenk, 1996; Iverson \& Prasad, 1998). However, locations into which a species might migrate may not contain the same suite of correlated conditions. These variations would most likely affect tree species during early life stages, since they are more sensitive to environmental conditions when small. The degree to which forest composition and productivity are affected by warming, as well as the relative range of 'suitable' habitats (Iverson \& Prasad, 1998) species will be able to survive in, will partly depend on the ability of species to acclimate (Ghannoum \& Way, 2011). In this study, the roughly equivalent differences between $T_{\text {opt }}$ and realized temperatures under both ambient and warmed conditions led to realized photosynthetic rates that were 90-95\% of optimal in both warming treatments, demonstrating that plants subjected to experimental warming were as well-matched to their environment as ambient plants. Thus, despite the modest shift in $T_{\text {opt }}$ of $1.1 \pm 0.21{ }^{\circ} \mathrm{C}$ in response to the warming treatment, acclimation was relatively complete, suggesting that direct negative impacts of modest climate warming on photosynthesis will be ameliorated as plants come near to optimizing photosynthesis with respect to temperatures experienced. However, indirect effects mediated through alterations of soil moisture will likely occur independent of but simultaneous with these thermal response shifts. Thus, omitting temperature acclimation from physiological and ecosystem models could result in predictions of carbon balance, ecosystem productivity, and species regeneration that are less realistic than can be achieved given the state of collective knowledge.

\section{Acknowledgements}

This article is based upon work supported by the U.S. Department of Energy, Office of Science, Office of Biological and Environmental Research under award number DE-FG02-07ER64456. Assistance with data collection was provided by Kyle Gill and Jianxiong Liao, as well as numerous summer interns.

\section{References}

Atkin OK, Loveys BR, Atkinson LJ et al. (2006) Phenotypic plasticity and growth temperature: understanding interspecific variability. Journal of Experimental Botany, 57, 267-281.

Battaglia M, Beadle C, Loughhead S (1996) Photosynthetic temperature responses of Eucalyptus globulus and Eucalyptus nitens. Tree Physiology, 16, 81-89.

Bernacchi CJ, Pimentel C, Long SP (2003) In vivo temperature response functions of parameters required to model RuBP-limited photosynthesis. Plant, Cell and Environment, 24, 253-259.

Berry J, Bjorkman O (1980) Photosynthetic response and adaptation to temperature in higher plants. Annual Review of Plant Physiology, 31, 491-543.

Bigler C, Braeker OU, Buggman $\mathrm{H}$ et al. (2006) Drought as an inciting mortality factor in Scots pine stands of the Valais, Switzerland. Ecosystems, 9, 330-343.

Bunce JA (2000) Acclimation of photosynthesis to temperature in eight cool and warm climate herbaceous $C_{3}$ species: temperature dependence of parameters of a biochemical photosynthesis model. Photosynthesis Research, 63, 59-67.

Christensen JH, Hewitson B, Busuioc A et al. (2007) Regional climate projections. In: Climate Change 2007: The Physical Science Basis Contribution of Working Group I to the Fourth Assesment Report of the Intergovernmental Panel on Climate Change. (eds Soloman S, Qin D, Manning M, Chen Z, Marquis M, Averyt KB, Tignor M, Miller HL), pp. 849-940. Cambridge University Press, Cambridge, UK and New York, USA.

Cunningham SC, Read J (2002) Comparison of temperate and tropical rainforest tree species: photosynthetic responses to growth temperature. Oecologia, 133, 112-119. 
Davis MB, Shaw RG (2001) Range shifts and adaptive responses to Quaternary climate change. Science, 292, 673-679.

Dillaway ND, Kruger EL (2010) Thermal acclimation of photosynthesis: a comparison of boreal and temperate tree species along a latitudinal transect. Plant, Cell and Environment, 33, 888-899.

Dougherty PM, Teskey RO, Phelps JE et al. (1979) Net photosynthesis and early growth trends of a dominant white oak (Quercus alba L.). Plant Physiology, 64, 930-935.

Farquahar GD, von Caemmerer S, Berry JA (1980) A biochemical model of photosynthetic $\mathrm{CO}_{2}$ assimilation on leaves of $\mathrm{C}_{3}$ species. Planta, 149, 78-90.

Frelich LE, Reich PB (1995) Spatial patterns and succession in a Minnesota southern boreal forest. Ecological Monographs, 65, 325-346.

Ghannoum O, Way DA (2011) On the role of ecological adaptation and geographic distribution in the response of trees to climate change. Tree Physiology, 31, 12731276.

Gremer JR, Kimball S, Angert AL et al. (2012) Variation in photosynthetic response to temperature in a guild of winter annual plants. Ecology, 93, 2693-2704.

Grigal DF, Ohmann LF (1975) Classification, description, and dynamics of upland plant communities within a Minnesota wilderness area. Ecological Monographs, 45, 389-407.

Gunderson CA, Norby RJ, Wullschleger SD (2000) Acclimation of photosynthesis and respiration to simulated climatic warming in northern and southern populations of Acer saccharum Marsh: laboratory and field evidence. Tree Physiology, 20, 87-96.

Gunderson CA, O'Hara KH, Campion CM et al. (2010) Thermal plasticity of photosynthesis: the role of acclimation in forest responses to a warming climate. Global Change Biology, 16, 2272-2286.

Han Q, Kawasaki T, Nakano T et al. (2004) Spatial and seasonal variability of temperature responses of biochemical photosynthesis parameters and leaf nitrogen content within a Pinus densiflora crown. Tree Physiology, 24, 737-744.

Hanson PJ, Wullschleger SD, Norby RJ et al. (2005) Importance of changing $\mathrm{CO}_{2}$, temperature, precipitation, and ozone on carbon and water cycles of an upland-oak forest: incorporating experimental results into model simulations. Global Change Biology, 77, 1402-1423.

Harris GC, Antoine V, Chan M et al. (2006) Seasonal changes in photosynthesis, protein composition and mineral content in Rhododendron leaves. Plant Science, 170, 314-325.

Heinselman ML (1973) Fire in the virgin forest of the boundary waters canoe area, Minnesota. Journal of Quaternary Research, 3, 329-382.

Hijmans RJ, Graham CH (2006) The ability of climate envelope models to predict the effect of climate change on species distributions. Global Change Biology, 12, 2272 2281.

Hikosaka K, Ishikawa K, Borjigidai A et al. (2006) Temperature acclimation of photosynthesis: mechanisms involved in the changes in temperature dependence of photosynthetic rate. Journal of Experimental Botany, 57, 291-302.

Hill RS, Read J, Busby JR (1988) The temperature-dependence of photosynthesis of some Australian temperate rainforest trees and its biogeographical significance. Journal of Biogeography, 15, 431-449.

Homann PS, Kapchinske JS, Boyce A (2007) Relations of mineral-soil C and N to climate and texture: regional differences within the conterminous USA. Biogeochemistry, 85, 303-316.

IPCC (2013) Climate Change 2013: The Physical Science Basis. Contribution of Working Group I to the Fifth Assessment Report of the Intergovernmental Panel on Climate Change, Cambridge University Press, Cambridge, UK and New York, NY USA.

Iverson LR, Prasad AM (1998) Predicting abundance of 80 tree species following climate change in the eastern United States. Ecological Monographs, 68, 465-485.

Jump AS, Hunt JM, Penualus J (2006) Rapid climate change-related growth decline at the southern range edge of Fagus sylvatica. Global Change Biology, 12, 2163-2174.

Kattge J, Knorr W (2007) Temperature acclimation in a biochemical model of photosynthesis: a reanalysis of data from 36 species. Plant, Cell and Environment, 30, 1176-1190.

Kositsup B, Montpied P, Kasemsap P et al. (2009) Photosynthetic capacity and temperature responses of rubber trees (Havea brasiliensis Mull Arg.) acclimate to changes in ambient temperatures. Trees - Structure and Function, 23, 357-365.

Loveys BR, Atkinson LJ, Sherlock DJ et al. (2003) Thermal acclimation of leaf and root respiration: an investigation comparing inherently fast- and slow-growing plant species. Global Change Biology, 9, 895-910.
Medlyn BE, Dreyer E, Ellsworth D et al. (2002a) Temperature response of parameters of a biochemically based model of photosynthesis. II. A review of experimental data. Plant, Cell and Environment, 25, 1167-1179.

Medlyn BE, Loustau D, Delzon S (2002b) Temperature response of parameters of a biochemically based model of photosynthesis. I. Seasonal changes in mature maritime pine (Pinus pinaster Ait.). Plant, Cell and Environment, 25, 1155-1165.

Niinemets Ü, Valladares F (2006) Tolerance to shade, drought, and waterlogging of temperate northern hemisphere trees and shrubs. Ecological Monographs, 76, 521547.

Onoda Y, Hikosaka K, Hirose T (2005) The balance between RuBP carboxylation and RuBP regeneration: a mechanism underlying the interspecific variation in acclimation of photosynthesis to seasonal change in temperature. Functional Plant Biology, 32, 903-910.

Ow LF, Griffin KL, Whitehead D et al. (2008) Thermal acclimation of leaf respiration but not photosynthesis in Populus deltoides x nigra. New Phytologist, 178, 123-134.

Pastor J, Post WM (1988) Response of northern forests to $\mathrm{CO}_{2}$-induced climate change. Nature, 334, 55-58.

Read J (1990) Some effects of acclimation temperature on net photosynthesis in some tropical and extra-tropical Australian Nothofagus species. Journal of Ecology, 78, 100-112.

Reich PB, Sendall KM, Rice K et al. (2015) Geographic range predicts photosynthetic and growth response to warming in co-occurring tree species. Nature Climate Change (in press).

Robakowski P, Li Y, Reich PB (2012) Local ecotypic and species range-related adaptation influence photosynthetic temperature optima in deciduous broadleaved trees. Plant Ecology, 213, 113-125.

Sage RF, Kubien DS (2007) The temperature response of $C_{3}$ and $C_{4}$ photosynthesis. Plant, Cell and Environment, 30, 1086-1106.

Sage RF, Way DA, Kubien DS (2008) Rubisco, Rubisco activase, and global climate change. Journal of Experimental Botany, 59, 1581-1595.

Schenk HJ (1996) Modeling the effects of temperature on growth and persistence of tree species: a critical review of tree population models. Ecological Modeling, 92, 132.

Schrader SM, Wise RR, Wacholtz WF et al. (2004) Thylakoid membrane responses to moderately high leaf temperature in pima cotton. Plant, Cell and Environment, 27, 725-735.

Schwartzberg EG, Jamieson MA, Raffa KF et al. (2014) Simulated climate warming alters phenological synchrony between an outbreak insect herbivore and host trees. Oecologia, 175, 1041-1049.

Slatyer RO, Ferrar PJ (1977) Altitudinal variation in photosynthetic characteristics of snow gum, Eucalyptus pauciflora Sieb. ex Spreng. I. Seasonal changes under field conditions in the Snowy Mountains area of south-eastern Australia. Australian Journal of Botany, 25, 1-20.

Sykes MT, Prentice IC (1996) Climate-change, tree species distributions and forest dynamics: a case study in the mixed-conifer northern hardwoods zone of northern Europe. Climatic Change, 34, 161-177.

Teskey RO, Will RE (1999) Acclimation of loblolly pine (Pinus taeda) seedlings to high temperatures. Tree Physiology, 19, 519-525.

Thomas CD, Cameron A, Green RE et al. (2004) Extinction risk from climate change. Nature, 427, 145-148.

Tjoelker MG, Oleksyn J, Reich PB (1998) Seedlings of five boreal tree species differ in acclimation of photosynthesis to elevated $\mathrm{CO}_{2}$ and temperature. Tree Physiology, 18, 715-726.

Veres JS, Williams GJ III (1984) Time course of photosynthetic temperature acclimation in Carex eleocharis Bailey. Plant, Cell and Environment, 7, 545-547.

Woodward FI (1987) Climate and Plant Distribution. Cambridge University Press, Cambridge, UK.. 177 pp.

Zhang S, Qingkang LI, Keping MA et al. (2001) Temperature-dependent gas exchange and stomatal/non-stomatal limitation of $\mathrm{CO}_{2}$ assimilation of Quercus liaotungensis under midday high irradiance. Photosynthetica, 39, 383-388.

Zimmermann NE, Yoccoz NG, Edwards TC Jr et al. (2009) Climatic extremes improve predictions of spatial patterns of tree species. Proceedings of the National Academy of Sciences, 106, 19723-19728. 


\section{Supporting Information}

Additional Supporting Information may be found in the online version of this article:

Figure S1. Relationship between mean $( \pm \mathrm{SE})$ photosynthetic rates measured at temperature optima $\left(A_{\mathrm{opt}}\right)$ and light-saturated photosynthetic rates $\left(A_{\max }\right)$ measured in situ. $A_{\text {opt }}$ was measured on detached foliage $(3-4 \mathrm{~h}$ following removal from the tree, on average) and $A_{\max }$ was measured on attached foliage.

Figure S2. Mean $\left( \pm\right.$ SE) rates of leaf diffusive conductance at six leaf temperatures $\left(12,17,22,27,32,37^{\circ} \mathrm{C}\right)$ for juvenile trees of four temperate and two boreal species. Open symbols, dashed lines represent species averages from the open canopy treatments and closed symbols, solid lines represent species averages from the closed canopy treatments.

Figure S3. Mean ( $\pm \mathrm{SE}$ ) internal leaf $\mathrm{CO}_{2}$ concentrations at six leaf temperatures $\left(12,17,22,27,32,37^{\circ} \mathrm{C}\right)$ for juvenile trees of four temperate and two boreal species. Open symbols, dashed lines represent species averages from the open canopy treatments and closed symbols, solid lines represent species averages from the closed canopy treatments.

Figure S4. Mean $( \pm \mathrm{SE})$ rates of net photosynthesis at six leaf temperatures $\left(12,17,22,27,32,37{ }^{\circ} \mathrm{C}\right)$ for juvenile trees of four temperate and two boreal species. Open symbols, dashed lines represent species averages from the open canopy treatments and closed symbols, solid lines represent species averages from the closed canopy treatments.

Figure S5. Mean $( \pm \mathrm{SE})$ rates of photosynthesis divided by internal leaf $\mathrm{CO}_{2}$ concentrations at six leaf temperatures $(12,17,22,27$, $32,37^{\circ} \mathrm{C}$ ) for juvenile trees of four temperate and two boreal species. Open symbols, dashed lines represent species averages from the open canopy treatments and closed symbols, solid lines represent species averages from the closed canopy treatments.

Table S1. ANOVA results for photosynthetic temperature optima $\left(T_{\mathrm{opt}}\right)$ of Acer rubrum, Betula papyrifera, and Populus tremuloides measured in 2009, 2010, and 2011.

Table S2. ANOVA results for photosynthetic rates at $T_{\text {opt }}\left(A_{\text {opt }}\right)$ of Acer rubrum, Betula papyrifera, and Populus tremuloides measured in 2009, 2010, and 2011.

Table S3. ANOVA results for the $b$ parameter (which denotes the shape of the temperature response curve) of Acer rubrum, Betula papyrifera, and Populus tremuloides measured in 2009, 2010, and 2011.

Table S4. ANOVA results for photosynthetic temperature optima $\left(T_{\text {opt }}\right)$ of all species by year in which the site, species' southern (lower latitude) range limits, overstory condition, warming treatment, and all 2- and 3-way interactions were the sources of variance.

Table S5. ANOva results for photosynthetic rates at $T_{\text {opt }}\left(A_{\text {opt }}\right)$ of all species by year in which the site, species' southern (lower latitude) range limits, overstory condition, warming treatment, and all 2- and 3-way interactions were the sources of variance.

Table S6. ANOva results for the $b$ parameter (which denotes the shape of the temperature response curve) of all species by year in which the site, species' southern (lower latitude) range limits, overstory condition, warming treatment, and all 2- and 3-way interactions were the sources of variance.

Table S7. Mean $\left( \pm \mathrm{SE}\right.$ ) photosynthetic temperature optima under ambient and $+2.9 \pm 0.01{ }^{\circ} \mathrm{C}$ warming by year and canopy condition. Temperature data shown are averaged across the 5 days prior to the measurement day. Mean air temperatures represent the time of day when plants are most photosynthetically active (09:00-15:00 hours).

Table S8. Mean ( \pm SE) photosynthetic temperature optima under ambient and $+2.9 \pm 0.01{ }^{\circ} \mathrm{C}$ warming by species and canopy condition. Temperature data shown are averaged across the 5 days prior to the measurement day. Mean air temperatures represent the time of day when plants are most photosynthetically active (09:00-15:00 hours).

Table S9. Mean ( \pm SE) photosynthetic temperature optima under ambient and $+2.9 \pm 0.01{ }^{\circ} \mathrm{C}$ warming by time of year and canopy condition. Temperature data shown are averaged across the 5 days prior to the measurement day. Mean air temperatures represent the time of day when plants are most photosynthetically active (09:00-15:00 hours). 